\title{
Pengaruh Penerapan Good Corporate Governance dan Keberadaan Awig-Awig terhadap Kinerja Keuangan Lembaga Perkreditan Desa dengan Budaya Tri Hita Karana sebagai Variabel Moderasi
}

\author{
Putu Rima Jayantari ${ }^{1}$, A. A. Ngurah Eddy Supriyadinata Gorda ${ }^{2}$ \\ 12 Universitas Pendidikan Nasional (Undiknas) Denpasar
}

\section{Keywords:}

good corporate

governance;

awig-awig;

tri hita karana;

financial performance

\section{ABSTRACT}

Abstract: This study aimed to determine the influence of the implementation Good Corporate Governance and the existence of awig-awig on the financial performance of LPD with Tri Hita Karana culture as a moderated variable in the LPD in Mengwi sub-district. This study used a saturated sampling method and the data analysis technique used was Moderated Regression Analysis. T test results show that:1) Good Corporate Governance had a positive effect on Financial Performance; 2) The existence of awig-awig had a positive effect on financial performance; 3) Tri Hita Karana Culture strengthens the influence of Good Corporate Governance on Financial Performance; 4) Tri Hita Karana's culture strengthens the influence of Awig-awig's Existence on Financial Performance.

\begin{abstract}
Abstrak: Penelitian ini bertujuan untuk mengetahui pengaruh penerapan Good Corporate Governance dan keberadaan awig-awig terhadap kinerja keuangan LPD dengan budaya Tri Hita Karana sebagai variabel yang dimoderasi dalam LPD di Kecamatan Mengwi. Penelitian ini menggunakan metode sampling jenuh dan teknik analisis data yang digunakan adalah Moderated Regression Analysis. Hasil uji T menunjukkan bahwa: 1) Tata kelola Perusahaan yang Baik memiliki pengaruh positif terhadap Kinerja Keuangan; 2) Keberadaan awig-awig memiliki efek positif pada kinerja keuangan; 3) Budaya Tri Hita Karana memperkuat pengaruh Good Corporate Governance terhadap Kinerja Keuangan; 4) Budaya Tri Hita Karana memperkuat pengaruh keberadaan awig-awig terhadap kinerja keuangan.
\end{abstract}

Alamat Korespondensi:

E-mail: rimajayantari123@gmail.com (Putu Rima Jayantari)

\section{Pendahuluan}

Di Provinsi Bali terdapat lembaga keuangan selain perbankan yang mempunyai peran besar dalam pembangunan ekonomi daerah. Lembaga keuangan mikro tersebut adalah Lembaga Perkreditan Desa (LPD) yang terdapat di masing-masing desa pekraman. LPD adalah sebuah badan usaha yang dimiliki oleh desa dimana badan usaha ini melaksanakan usahanya di lingkungan desa dan untuk karna desa hal ini sesuia dengan Perda Provinsi Bali No. 3 tahun 2007. Kesederhanaan kaidah yang digunakan LPD tidak mengurangi manfaat yang didapatkan oleh masyarakat, seperti memberikan pelayanan sesuai dengan situasi dan kondisi masyarakat, pelayanan tersebar dan menjangkau berbagai sektor usaha masyarakat. Selain itu, sebagian laba yang diperoleh LPD juga digunakan untuk mendanai kegiatan adat di desa pekraman setempat. LPD juga menjalankan fungsi 
intermediasi melalui penerimaan tabungan dan penyaluran kredit, utamanya dari dan kepada masyarakat, khususnya masyarakat di desa adat tempat LPD didirikan.

Permasalahan yang sering dihadapi LPD dala melaksanakan kegiatan usahanya adalah terjadinya kredit macet. Terjadinya kredit macet ini tentu akan menghambat perkembangan LPD tersebut. Selain kredit macet, penggelapam dana yang dilakukam oleh pihak pengurus LPD juga sering terjadi. Hal ini tentu akan merugikan banyak pihak, pihak yang paling dirugikan dalam masalah ini tentu saja para nasabah LPD tersebut. Salah satu kasus penggelapan dana LPD yang terjadi di kecamatan Mengwi adalah kasus penggelapan dana yang di lakukan oleh mantan ketua LPD Desa Kapal. Dilansir dari laman Tribun Bali tanggal 24 Oktober 2018, mantan ketua LPD Desa Kapal tersebut melakukan penggelapan dana sebesar 15 Milyar. Pada awalnya LPD desa Kapal tercatat memiliki keuangan yang sehat, namun pada tahun 2016 mulai tercium ketidakberesan di dalam laporan keuangan LPD tersebut. Maka dari itu, untuk memperkecil kemungkinan terjadinya permasalahan-permasalahan tersebut, LPD wajib melakukan pemeriksaan secara berkala terhadap kinerja keuangannya. Dengan dilakukannya pemeriksaan terhadap kinerja keuangan, diharapkan dapat memperkecil terjadinya penyelewengan-penyelewengan yang dilakukan oleh pihak-pihak yang tidak bertanggungjawab.

Menurut Ikatan Akuntan Indonesia, kinerja keuangan merupakan kemampuan sebuah perusahaan di dalam mengendalikan dan mengelola sumber daya yang dimilikinya. Kinerja keuangan mencerminkan prestasi kerja pada suatu periode yang tertuang pada laporan keuangan. Kinerja keuangan digunakan untuk,mengukur kinerja pada masa yang bersangkutan dengan membandingkan kinerja di masa lalu. Biasanya profitabilitas sebuah perusahaan diukur dengan rasio profitabilitas, dikarenakan rasio profitabilitas mencakup rasio aktivitas, rasio likuiditas dan rasio utang. Rasio profitabilitas yang sering digunakan adalah Return On Assets (ROA). ROA adalah rasio keuangan yang, digunakan untuk,mengukur profitabilitas perusahaan. ROA dapat menunjukkan efisiensi dari aset yang digunakan dalam menghasilkan laba.

Selain dengan melakukan pemeriksaan secara berkala terhadap kinerja keuangan LPD, untuk memperkecil kemungkinan-kemungkinan terjadinya permasalahan-permasalahan tersebut, maka perlu diterapkan prinsip Good Corporate Governance. Menurut Forum for Corporate Governance in Indonesia (FCGI), Good Corporate Governance adalah sebua peraturan yang menetapkan dan mengatur hubungan antara pemerintah, karyawan, pihak kreditur, pemangku kepentingan pengurus, serta para pemegang kepentingan internal dan eksternal lainnya atau dapat disimpulkan Good Corporate Governance adalah sistem yang mengarahkan dan mengendalikan perusahaan. Dengan diterapkannya Good Corporate Governance pada LPD akan mencegah terjadinya kegiatan menguntungkan diri sendiiri dan kesalahan di dalam pengambilan keputusan sehingga secara otomatis akan meningkatkan nilai LPD yang tercermin pada kinerja LPD tersebut (Setyawan dan Putri, 2013). Selain menerapkannya Good Corporate Governance, LPD sebagai lembaga keuangan milik desa juga perlu menerapkan awig-awig desa pekraman sebagai landasan hukum LPD. Dengan diberlakukannya sanksi tegas yang dilandasi oleh awig-awig desa pekraman diharapkan akan mampu memberikan efek jera kepada oknum-oknum yang tidak bertanggung jawab. Diterapkannya Good Corporate Governance dan pemberlakukan sanksi tegas yang dilandasi oleh awig-awig desa pekraman sebagai landasan hukum LPD bertujuaan agar masyarakat lebih percaya terhadap LPD sebagai lembaga keuangan milik desa.

Dalam penerapan Good Corporate Governance untuk mencapai kinerja keuangan yang baik, maka diperlukan juga sebuah konsep kearifan lokal yang menunjang penerapan Good Corporate Governance tersebut. Konsep kearifan lokal tersebut adalah budaya Tri Hita Karana. Konsep budaya Tri Hita Karana adalah konsep harmonisasi hubungan yang selalu dijaga oleh masyarakat Hindu di Bali, yang meliputi: pawongan (hubungan manusia dan manusia), parahyangan (hubungan manusia dan Tuhan), palemahan (hubungan manusia dan lingkungan) yang bersumber dari kitab Baghawad Gita. Konsep Tri Hita Karana digunakan karena dianggap mampu menciptakan budaya kejujuran (Adiputra, et al.,2014), keterbukaan, dan bantuan (creating a culture of honesty, openness, and assistance) serta mengeliminasi peluang terjadinya tindakan kecurangan (eliminating fraud opportunities) (Saputra, 2012). Maka dari itu, pengunaan konsep budaya Tri,Hita Karana dalam 
kegiatan LPD bertujuan untuk mencegah terjadinya tindakan kecurangan yang dilakukan oleh oknum-oknum yang tidak bertanggungjawab.

Berkaitan dengan kajian mengenai pengaruh Good Corporate Governance dan Tri Hita Karana terhadap kinerja keuangan sebenarnya sudah cukup banyak diteliti (Arjasa, 2017; Astini, 2019; Cahyani, 2016; Dewi, 2014; Made dan Erawati, 2017; Nucahyani dkk, 2011; Omika dkk, 2017; Omika dkk, 2018; Pradnyani, 2018; Prasinta, 2013; Putri dkk, 2017; Sujana, 2018). Serangkaian penelitian tersebut menemukan bahwa terdapat hubungan yang positif atara penerapan GCG dan awig-awig terhadap kinerja lembaga keuangan. Studi yang dilakukan oleh Nilawati (2016) dan Mulyawan \& Badera (2017) memperluas kajian mengenai hubungan antara GCG terhadap kinerja lembaga keuangan dengan melibatkan Tri Hita Karana sebagai pemoderasi. Kedua kajian tersebut menemukan bahwa keberadaan Tri Hita Karana pada variabel GCG adalah bersifat memperkuat, artinya penerapan GCG yang semakin baik dengan diikuti oleh penerapan budaya Tri Hita Karana akan secara bersama-sama meningkatkan kinerja lembaga keuangan (LPD). Berkaitan dengan sejumlah penelitian tersebut, peneliti tertarik untuk melihat lebih jauh peran variabel Tri Hita Karana sebagai pemoderasi. Berbeda dengan beberapa kajian sebelumnya kajian ini akan memfokuskan diri untuk melihat pengaruhnya terhadap kinerja keuangan dengan memasukkan variabel GCG dan wigawig sebagai variabel bebas.

\section{Metode}

Penelitian ini merupakan jenis penelitian kuantitatif. Jenis penelitian ini digunakan untuk melihat pengaruh penerapan good corporate governance dan keberadaan awig-awig terhadap kinerja keuangan lembaga perkreditan desa dengan budaya tri hita karana sebagai variabel moderasi. Pengumpulan data dalam penelitian ini dilakukan di LPD se-kecamatan Mengwi. Populasi datanya adalah LPD yang ada di kecamatan Mengwi yang berjumlah 38 LPD. Teknik sampling yang digunakan adalah teknik sampling jenuh. Data kuantitatif diperoleh dari pengisian kuisioner yang dilakukan LPD se-Kecamatan Mengwi.

Sumber data adalah data primer, yaitu sumber data yang langsung memberikan data kepada pengumpul data (Sugiyono, 2014). Selain itu, teknik analisis data menggunakan analisis regresi moderasi (Moderating Regresion Analysis). Uji MRA adalah aplikasi khusus regresi linier berganda. Pengujian MRA digunakan untuk menjelaskan pengaruh variabel pemoderasi, yaitu dalam memperlemah, atau memperkuat hubungan variabel independen dan dependen.

\section{Hasil dan Pembahasan}

Penelitian ini dilaksanakan di LPD di kecamatan Mengwi, Badung. Kecamatan Mengwi dipilih sebagai lokasi penelitian ini karena masyarakat di kecamatan Mengwi masih memegang teguh adat dan istiadat yang dianutnya. Lokasi ini tentu sesuai dengan,judul penelitian,yang diambil oleh penulis. Kuisioner disebarkan ke 38 LPD di kecamatan Mengwi, namun hanya 36 kuisioner yang terkumpul kembali dan terdapat 2 kuisioner yang tidak terkumpul dikarenakan 1 buah LPD sedang tidak beroperasi dan 1 kuisioner hilang. Sehingga dalam,penelitian ini diperoleh data dari 36 orang responden dari 36 LPD di kecamatan Mengwi dengan jabatan sebagai ketua LPD.

\section{Hasil Uji Asumsi Klasik}

1. Uji Multikolinearitas

Tabel 1. Hasil Uji Multikolinieritas

\begin{tabular}{lll}
\hline \multicolumn{2}{l}{$\begin{array}{ll}\text { Coefficients } \\
\text { Model }\end{array}$} & \multicolumn{2}{l}{$\begin{array}{l}\text { Collinearity } \\
\text { Statistics } \\
\end{array}$} & Tolerance & VIF \\
\hline $1 \quad$ GCG & .461 & 2.168 \\
\hline
\end{tabular}




\begin{tabular}{ccc}
\hline AW & .289 & 3.458 \\
THK & .292 & 3.424 \\
GCG*THK & .458 & 2.181 \\
AW*THK & .826 & 1.211 \\
a. Dependent Variable: Perf & \\
\hline
\end{tabular}

Berdasarkan tabel 1 di atas didapat bahwa variabel Good Corporate Governance memiliki tolerance lebihbesar dari 0,1 $(0,461>0,1)$ dan VIF lebih kecil dari $10(2,168<10)$. Variabel Keberadaan Awig-awig memiliki tolerance lebih besar dari 0,1 $(0,286>0,1)$ dan VIF lebih kecil dari $10(3,458<10)$, variabel budaya Tri Hita Karana memiliki tolerance lebih besar dari 0,1 $(0,292>0,1)$ dan VIF lebih kecil dari $10(3,424<10)$, variabel Good Corporate Governance dengan budaya Tri Hita Karana sebagai pemoderasi memiliki tolerance lebih besar dari 0,1 $(0,458>0,1)$ dan VIF lebih kecil dari $10(2,181<10)$ dan variabel Keberadaan awig-awig dengan budaya Tri Hita Karana sebagai pemoderasi memiliki tolerance lebih besar dari $0,1(0,826>0,1)$ dan VIF lebih kecil dari $10(1,211<10)$. Dengan demikian dapat dinyakatakan tidak terjadi multikolinieritas.

2. Uji Normalitas

Tabel 2. Hasil Uji Normalitas

\begin{tabular}{|c|c|c|}
\hline \multicolumn{3}{|c|}{ One-Sample Kolmogorov-Smirnov Test } \\
\hline & & $\begin{array}{c}\text { Unstandardized } \\
\text { Residual }\end{array}$ \\
\hline $\mathrm{N}$ & & 36 \\
\hline Normal & Mean & .0000000 \\
\hline Parameters ${ }^{\mathrm{a}, \mathrm{b}}$ & Std. Deviation & 1.27011209 \\
\hline Most Extreme & Absolute & .100 \\
\hline \multirow[t]{2}{*}{ Differences } & Positive & .065 \\
\hline & Negative & -.100 \\
\hline \multicolumn{2}{|l|}{ Test Statistic } & .100 \\
\hline \multicolumn{2}{|c|}{ Asymp. Sig. (2-tailed) } & $.200^{c, d}$ \\
\hline \multicolumn{3}{|c|}{ a. Test distribution is Normal. } \\
\hline \multicolumn{3}{|c|}{ b. Calculated from data. } \\
\hline \multicolumn{3}{|c|}{ c. Lilliefors Significance Correction. } \\
\hline \multicolumn{3}{|c|}{ d. This is a lower bound of the true significance. } \\
\hline
\end{tabular}

Berdasarkan Tabel 2 dapat dilihat bahwa nilai Kolmogorov Sminarnov (K-S) sebesar 0,100 dan nilai Asymp Sig (2-tailed) sebesar 0,200, hasil tersebut mengindikasikan bahwa model persamaan regresi tersebut berdistribusi normal karena nilai Asymp Sig (2-tailed) lebih besar dari nilai alpha: 0,05 $(0,200>0,05)$. Hasil uji normalitas juga dapat dilihat berdasarkan grafik $p-p$ plot pada gambar 1 berikut. 


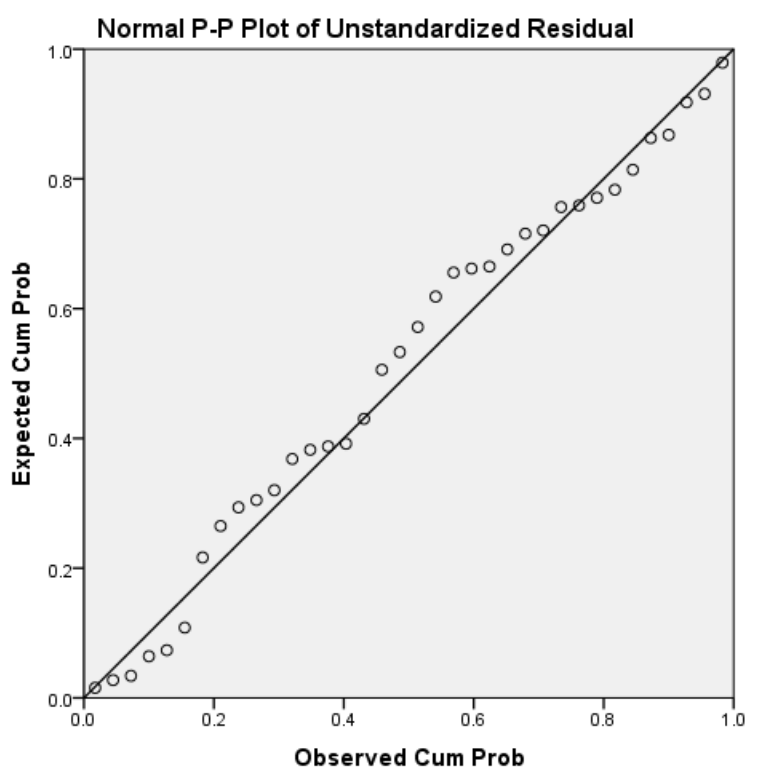

Gambar 1. Grafik P-P Plot

Berdasarkan gambar di atas, dapat dilihat seluruh sebaran data mendekati rata-rata dan membentuk kurva normal.sebaran data akan berada dekat dengan garis regresi atau garis diagonal sehingga data berdistribusi normal.

3. Uji Heteroskedastisitas

Tabel 3. Hasil Uji Heteroskedastisitas

\begin{tabular}{|c|c|c|c|c|c|c|}
\hline \multicolumn{7}{|c|}{ Coefficients $^{\mathrm{a}}$} \\
\hline \multirow{2}{*}{\multicolumn{2}{|c|}{ Model }} & \multicolumn{2}{|c|}{$\begin{array}{l}\text { Unstandardized } \\
\text { Coefficients }\end{array}$} & \multirow{2}{*}{$\begin{array}{c}\text { Standardized } \\
\text { Coefficients } \\
\text { Beta }\end{array}$} & \multirow[t]{2}{*}{$\mathrm{t}$} & \multirow[t]{2}{*}{ Sig. } \\
\hline & & B & Std. Error & & & \\
\hline \multirow[t]{6}{*}{1} & (Constant) & .295 & 1.234 & & .239 & .812 \\
\hline & GCG & -.050 & .073 & -.180 & -.690 & .495 \\
\hline & $A W$ & -.060 & .107 & -.184 & -.558 & .581 \\
\hline & THK & .198 & .151 & .430 & 1.312 & .200 \\
\hline & GCG*THK & .000 & .002 & -.059 & -.224 & .824 \\
\hline & AW*THK & .000 & .001 & .053 & .273 & .787 \\
\hline
\end{tabular}

Pada Tabel 3 dapat dilihat bahwa nilai signifikansi dari variabel Good Corporate Governance sebesar 0,495. Nilai signifikansi dari variabel Keberadaan Awig-awig sebesar 0,581. Nilai signifikansi dari variabel budaya Tri Hita Karana sebesar 0,200. Nilai signifikansi dari variabel Good Corporate Governance dengan Budaya Tri Hita Karana sebagai pemoderasi sebesar 0,824, Nilai signifikansi dari variabel Keberadaan Awig-awig dengan BudayaTri Hita Karana sebagai pemoderasi sebesar 0,787 . Nilai tersebut lebih besar dari 0,05 yang berarti tidak terdapat pengaruh antara variabel bebas terhadap absolute residual. Dengan demikian, model yang dibuat tidak mengandung gejala heteroskedastisitas. Hasil uji heteroskedastisitas juga dapat dilihat berdasarkan grafik scatterplot pada gambar 2 berikut. 


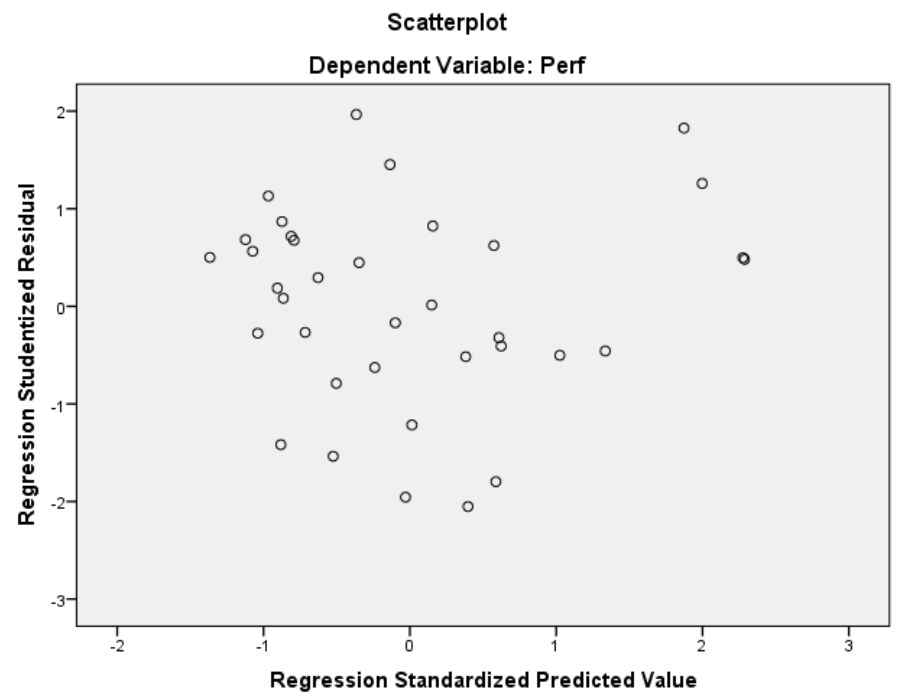

Gambar 2. Grafik Scatterplot

Berdasarkan gambar diatas, dapat dilihat titik-titik menyebar diatas dan dibawah 0 pada sumbu $Y$ serta tidak membentuk pola yang jelas, sehingga dapat disimpulkan tidak terjadi heteroskedastisitas pada data.

\section{Hasil Uji MRA (Moderated Regression Analysis)}

Tabel 4. Hasil Analisis MRA (Moderated Regression Analysis)

\begin{tabular}{lccccc}
\hline Model & \multicolumn{5}{c}{ Coefficients $^{\text {a }}$} \\
& $\begin{array}{c}\text { Unstandardized } \\
\text { Coefficients } \\
\text { Standardized } \\
\text { Coefficients } \\
\text { Beta }\end{array}$ & $\mathrm{t}$ & Sig. \\
\hline $1 \quad$ (Constant) & 3.587 & 2.179 & & 1.646 & .110 \\
GCG & .291 & .129 & .233 & 2.250 & .032 \\
AW & .413 & .190 & .284 & 2.176 & .038 \\
THK & .672 & .267 & .327 & 2.514 & .018 \\
GCG*THK & .007 & .003 & .237 & 2.283 & .030 \\
AW*THK & .003 & .003 & .078 & 2.109 & .039 \\
R Square & & & & & 0,852 \\
Adjusted R Square & & & & & 0,827 \\
F Hitung & & & & & 34,485 \\
Signifikansi F & & & & & 0,000 \\
\hline
\end{tabular}

Berdasarkan hasil analisis MRA seperti yang disajikan pada Tabel 4.7, maka dapat dibuat persamaan struktural sebagai berikut:

$Y=3,587+0,291 X_{1}+0,413 X_{2}+0,672 M+0,007 X_{1} M+0,003 X_{2} M$

Hasil persamaan tersebut menunjukkan besar dan arah pengaruh masing-masing variabel bebas pada variabel terikat. Koefisien regresi yang bertanda positif berarti mempunyai pengaruh yang searah pada Kinerja Keuangan. Koefisien-koefisiennya sebagai berikut :

Nilai konstanta diasumsikan bahwa tanpa ditambahkan variabel Good Corporate Governance, Keberadaan Awig-awig dan Budaya Tri Hita Karana maka nilai Kinerja Keuangan sebesar 3,587 . 
a. Apabila $X_{1}$ (Good Corporate Governance) mengalami peningkatan sebesar 1 satuan dengan asumsi Keberadaan Awig-awig dan Budaya Tri Hita Karana dianggap tetap maka Kinerja Keuangan akan meningkat sebesar 0,291 satuan.

b. Apabila $\mathrm{X}_{2}$ (Keberadaan Awig-awig) mengalami peningkatan sebesar 1 satuan dengan asumsi Good Corporate Governance dan Budaya Tri Hita Karana dianggap tetap maka Kinerja Keuangan akan meningkat sebesar 0,413 satuan.

c. Apabila M (Budaya Tri Hita Karana) mengalami peningkatan sebesar 1 satuan dengan asumsi Keberadaan Awig-awig dan Good Corporate Governance dianggap tetap maka Kinerja Keuangan akan meningkat sebesar 0,672 satuan.

d. Apabila $\mathrm{X}_{1} \mathrm{M}$ (Good Corporate Governance dengan budaya Tri Hita Karana sebagai pemoderasi) mengalami peningkatan sebesar 1 satuan dengan asumsi Keberadaan Awig-awig dianggap tetap maka Kinerja Keuangan akan meningkat sebesar 0,007 satuan.

e. Apabila $\mathrm{X}_{2} \mathrm{M}$ (Keberadaan Awig-awig dengan Budaya Tri Hita Karana sebagai pemoderasi) mengalami peningkatan sebesar 1 satuan dengan asumsi Good Corporate Governance dianggap tetap maka Kinerja Keuangan akan meningkat sebesar 0,003 satuan.

\section{Hasil Pengujian Hipotesis}

1. Koefisien Determinasi

Tabel 5. Hasil Analisis Koefisien Determinasi

\begin{tabular}{lcccc}
\hline Model & $\mathrm{R}$ & \multicolumn{3}{c}{ Model Summary } \\
$\mathrm{R}$ & $\begin{array}{c}\text { Adjusted R } \\
\text { Square }\end{array}$ & $\begin{array}{c}\text { Std. Error of } \\
\text { the Estimate }\end{array}$ \\
\hline 1 & $.923^{\text {a }}$ & .852 & .827 & 1.372 \\
a. Predictors: (Constant), AW*THK, THK, GCG*THK, GCG, AW \\
b. Dependent Variable: Perf
\end{tabular}

Berdasarkan tabel 4.8, besarnya pengaruh variabel bebas terhadap variabel terikat yang ditunjukkan oleh nilai determinasi total (Adjused $R$ Square) sebesar 0,827 mempunyai arti bahwa sebesar 82,7\% variasi Good Corporate Governance, Keberadaan Awig-awig dan Budaya Tri Hita Karana sebagai pemoderasi terhadap Kinerja Keuangan, sedangkan sisanya sebesar 17,3\% dijelaskan oleh faktor lain yang tidak dimasukkan ke dalam model.

2. Uji Kelayakan Model (Uji F)

Tabel 6. Hasil Uji Kelayakan Model (Uji F)

\begin{tabular}{|c|c|c|c|c|c|c|}
\hline \multicolumn{7}{|c|}{ ANOVA $^{a}$} \\
\hline \multicolumn{2}{|c|}{ Model } & $\begin{array}{l}\text { Sum of } \\
\text { Squares }\end{array}$ & df & $\begin{array}{l}\text { Mean } \\
\text { Square }\end{array}$ & $\mathrm{F}$ & Sig. \\
\hline \multirow[t]{3}{*}{1} & Regression & 324.511 & 5 & 64.902 & 34.485 & $.000^{b}$ \\
\hline & Residual & 56.461 & 30 & 1.882 & & \\
\hline & Total & 380.972 & 35 & & & \\
\hline \multicolumn{3}{|c|}{ a. Dependent Variable: Perf } & \multicolumn{3}{|c|}{ b. Predictors: (Constant), AW*THK, THK, GCG*THK, GCG, AW } & \\
\hline
\end{tabular}

Berdasarkan tabel 4.9, dapat dilihat nilai signifikan sebesar .0,000 kurang dari 0,05 $(0,000<0,05)$ sehingga model dalam penelitian ini layak atau variabel bebas mampu menjelaskan variabel terikat, dengan kata lain variabel independent secara simultan atau bersama berpengaruh terhadap variabel dependent. 
3. Uji Parsial (Uji t)

Tabel 7. Hasil Uji Parsial (Uji t)

\begin{tabular}{|c|c|c|c|c|c|c|}
\hline \multicolumn{7}{|c|}{ Coefficients $^{\mathrm{a}}$} \\
\hline \multirow{2}{*}{\multicolumn{2}{|c|}{ Model }} & \multicolumn{2}{|c|}{$\begin{array}{l}\text { Unstandardized } \\
\text { Coefficients }\end{array}$} & \multirow{2}{*}{$\begin{array}{c}\text { Standardized } \\
\text { Coefficients } \\
\text { Beta } \\
\end{array}$} & \multirow[t]{2}{*}{$\mathrm{t}$} & \multirow[t]{2}{*}{ Sig. } \\
\hline & & B & Std. Error & & & \\
\hline \multirow[t]{6}{*}{1} & (Constant) & 3.587 & 2.179 & & 1.646 & .110 \\
\hline & GCG & .291 & .129 & .233 & 2.250 & .032 \\
\hline & AW & .413 & .190 & .284 & 2.176 & .038 \\
\hline & THK & 672 & .267 & .327 & 2.514 & .018 \\
\hline & GCG*THK & .007 & .003 & .237 & 2.283 & .030 \\
\hline & AW*THK & .003 & .003 & .078 & 2.109 & .039 \\
\hline \multicolumn{7}{|c|}{ a. Dependent Variable: Perf } \\
\hline
\end{tabular}

a. Pengaruh Good Corporate Governance Terhadap Kinerja Keuangan

Untuk menguji $\mathrm{H}_{0}$ diterima atau ditolak dapat dilihat dalam penjabaran sebagai berikut Hipotesis:

$\mathrm{H}_{0}$ : Good Corporate Governance tidak berpengaruh positif terhadap Kinerja Keuangan.

$\mathrm{H}_{1}$ : Good Corporate Governance berpengaruh positif terhadap Kinerja, Keuangan.

Berdasarkan tabel 4.10, dapat dilihat nilai signifikan untuk variabel Good Corporate Governance sebesar 0,032 kurang dari 0,05 $(0,032<0,05)$ dengan nilai koefisien positif 0,291 , sehingga $\mathrm{H}_{1}$ diterima, dengan kata lain Good Corporate Governance berpengaruh positif terhadap Kinerja Keuangan.

b. Pengaruh Keberadaan Awig-awig Terhadap Kinerja Keuangan

Untuk menguji $\mathrm{H}_{0}$ diterima atau ditolak dapat dilihat dalam penjabaran sebagai berikut :

Hipotesis:

$\mathrm{H}_{0}$ : Keberadaan Awig-awig tidak berpengaruh positif terhadap Kinerja Keuangan.

$\mathrm{H}_{2}$ : Keberadaan Awig-awig berpengaruh positif terhadap Kinerja Keuangan.

Berdasarkan tabel 4.10, dapat dilihat nilai signifikan untuk variabel Keberadaan Awig-awig sebesar 0,038 kurang dari 0,05 $(0,038<0,05)$ dengan nilai koefisien posititf 0,413, sehingga $\mathrm{H}_{2}$ diterima, dengan kata lain keberadaan awig-awig berpengaruh positif pada Kinerja Keuangan.

c. Pengaruh Good Corporate Governance Terhadap Kinerja Keuangan dengan Budaya Tri Hita Karana Sebagai Variabel Moderasi

Untuk menguji $\mathrm{H}_{0}$ diterima atau ditolak dapat dilihat dalam penjabaran sebagai berikut : Hipotesis:

$\mathrm{H}_{0}$ : Budaya Tri Hita Karana tidak memperkuat pengaruh Good Corporate Governance terhadap Kinerja Keuangan.

$\mathrm{H}_{3}$ : Budaya Tri Hita Karana memperkuat pengaruh Good Corporate Governance terhadap Kinerja Keuangan.

Berdasarkan tabel 4.10, dapat dilihat nilai signifikan untuk variabel Good Corporate Governance dengan budaya Tri Hita Karana sebagai pemoderasi sebesar 0,030 kurang dari $0,05(0,030<0,05)$ dengan nilai koefisien positif 0,007 , sehingga $\mathrm{H}_{3}$ diterima, dengan kata lain budaya Tri Hita Karana memperkuat pengaruh Good Corporate Governance terhadap Kinerja Keuangan.

d. Pengaruh Keberadaan Awig-awig Terhadap Kinerja Keuangan dengan Budaya Tri Hita Karana Sebagai Variabel Moderasi 
Untuk menguji $\mathrm{H}_{0}$ diterima atau ditolak dapat dilihat dalam penjabaran sebagai berikut : Hipotesis:

$\mathrm{H}_{0}$ : Budaya Tri Hita Karana tidak memperkuat pengaruh Keberadaan Awig-awig pada Kinerja Keuangan.

$\mathrm{H}_{4}$ : Budaya Tri Hita Karana memperkuat pengaruh Keberadaan Awig-awig pada Kinerja Keuangan.

Berdasarkan tabel 4.10, dapat dilihat nilai signifikan untuk variabel Keberadaan Awig-awig dengan Budaya Tri Hita Karana sebagai pemoderasi sebesar 0,039 kurang dari dari 0,05 $(0,039<0,05)$ dengan nilai koefisien positif 0,003 , sehingga $\mathrm{H}_{4}$ diterima, dengan kata lain Budaya Tri Hita Karana memperkuat pengaruh Keberadaan Awig-awig terhadap Kinerja Keuangan.

Berdasarkan hasil analisis yang dilakukan, dapat dilihat nilai signifikan untuk variabel Good Corporate Governance sebesar 0,032 kurang dari 0,05 $(0,032<0,05)$ dengan nilai koefisien positif 0,291 , sehingga $\mathrm{H}_{1}$ diterima, dengan kata lain Good Corporate Governance berpengaruh positif terhadap Kinerja Keuangan. Hal ini berarti semakin meningkat Good Corporate Governance maka akan semakin meningkat Kinerja Keuangan, sebaliknya semakin menurun Good Corporate Governance maka Kinerja Keuangan akan semakin menurun. Hasil ini sesuai dengan penelitian yang dilakukan oleh Wita Bulandari dan Eka Damayanthi (2014), yaitu good corporate governance berpengaruh signifikan positif terhadap kinerja keuangan LPD.

Berdasarkan hasil analisis yang dilakukan, dapat nilai signifikan untuk variabel keberadaan awig-awig sebesar 0,038 kurang dari 0,05 $(0,038<0,05)$ dengan nilai koefisien posititf 0,413, sehingga $\mathrm{H}_{2}$ diterima, dengan kata lain keberadaan awig-awig berpengaruh positif pada kinerja keuangan. Hal ini berarti semakin meningkat keberadaan awig-awig maka Kinerja Keuangan akan semakin meningkat, sebaliknya semakin menurun keberadaan awig-awig maka kinerja keuangan akan semakin menurun. Hasil ini sesuai dengan penelitian yang dilakukan oleh Atmadja, Darmawan, dan Saputra (2014), yaitu proteksi awig- awig memiliki pengaruh positif dan signifikan terhadap kinerja LPD.

Berdasarkan hasil analisis yang dilakukan, dapat dilihat nilai signifikan untuk variabel Good Corporate Governance dengan Budaya Tri Hita Karana sebagai pemoderasi sebesar 0,030 kurang dari $0,05(0,030<0,05)$ dengan nilai koefisien positif 0,007 , sehingga $\mathrm{H}_{3}$ diterima, dengan kata lain Budaya Tri Hita Karana memperkuat pengaruh Good Corporate Governance terhadap Kinerja Keuangan. Hal ini berarti semakin meningkat Good Corporate Governance dengan Budaya Tri Hita Karana sebagai pemoderasi maka akan semakin meningkat, sebaliknya semakin menurun Good Corporate Governance dengan BudayaTri Hita Karana sebagai pemoderasi maka Kinerja Keuangan akan semakin menurun. Hasil ini sesuai dengan penelitian yang dilakukan oleh Mulyawan, Wirama, dan Badera (2017) yaitu budaya Tri Hita Karana memperkuat pengaruh good corporate governance pada kinerja LPD.

Berdasarkan hasil analisis yang dilakukan, dapat dilihat nilai signifikan untuk variabel Keberadaan Awig-awig dengan Budaya Tri Hita Karana sebagai pemoderasi sebesar 0,039 kurang dari dari $0,05(0,039<0,05)$ dengan nilai koefisien positif 0,003 , sehingga $\mathrm{H}_{4}$ diterima, dengan kata lain Budaya Tri Hita Karana memperkuat pengaruh Keberadaan Awig-awig pada kinerja keuangan. Hal ini berarti semakin meningkat Keberadaan awig-awig dengan budaya Tri Hita Karana sebagai pemoderasi maka maka kinerja keuangan akan semakin meningkat, sebaliknya semakin menurun Keberadaan Awig-awig dengan budaya Tri Hita Karana sebagai pemoderasi maka kinerja keuangan akan semakin menurun. Hasil ini sesuai dengan penelitian yang dilakukan oleh Nilayani (2016) yaitu pengaruh interaksi Tri Hita Karana dan proteksi awig-awig terhadap kinerja LPD adalah positif dan signifikan dan hasil kajian (Mulyawan et al., 2017) yang juga menemukan bahwa variabel budaya Tri Hita Karana pada variabel GCG adalah bersifat memperkuat, artinya penerapan GCG yang semakin baik dengan diikuti oleh penerapan budaya Tri Hita Karana akan secara bersama-sama meningkatkan kinerja. 


\section{Simpulan}

Berdasarkan hasil analisis penelitian dan hasil pembahasan sebelumnya maka simpulan dari penelitian ini adalah sebagai berikut:

1) Good Corporate Governance berpengaruh positif terhadap kinerja keuangan. Hal ini berarti semakin meningkat Good Corporate Governance maka Kinerja Keuangan akan semakin meningkat, sebaliknya semakin menurun Good Corporate Governance maka kinerja keuangan akan semakin menurun.

2) Keberadaan awig-awig berpengaruh positif terhadap Kinerja Keuangan. Hal ini berarti semakin meningkat Keberadaan awig-awig maka Kinerja Keuangan akan semakin meningkat, sebaliknya semakin menurun keberadaan awig-awig maka kinerja keuangan akan semakin menurun.

3) Budaya Tri Hita Karana memperkuat pengaruh Good Corporate Governance terhadap Kinerja Keuangan. Hal ini berarti semakin meningkat Good Corporate Governance dengan budaya Tri Hita Karana sebagai pemoderasi maka Kinerja Keuangan akan semakin meningkat atau, sebaliknya semakin menurun Good Corporate Governance dengan Budaya Tri Hita Karana sebagai pemoderasi maka Kinerja Keuangan akan semakin menurun.

4) Budaya Tri Hita Karana memperkuat pengaruh Keberadaan awig-awig pada kinerja keuangan. Hal ini berarti semakin meningkat Keberadaan Awig-awig dengan Budaya Tri Hita Karana sebagai pemoderasi maka Kinerja Keuangan akan semakin meningkat atau, sebaliknya semakin menurun Keberadaan awig-awig dengan budaya Tri Hita Karana sebagai pemoderasi maka kinerja keuangan akan semakin menurun.

\section{Daftar Pustaka}

Arjasa, G. 2017. Pengaruh Good Corporate Governance dan Budaya Organisasi Terhadap Kinerja Keuangan Lembaga Perkreditan Desa (LPD) di Kecamatan Kuta Selatan. Skripsi Akuntansi Universitas Pendidikan Nasional.

Astini, A., \& Yadnyana, K. 2019. Pengaruh Penerapan GCG dan Budaya Tri Hita Karana pada Kinerja Keuangan LPD Di Kabupaten Jembrana. 27, 90-118. Retrieved from http://www.tjyybjb.ac.cn/CN/article/downloadArticleFile.do?attachType=PDF\&id=9987

Cahyani, T. (2016). Pengaruh Penerapan Prinsip - Prinsip Good Corporate Governance dan Filosopi Tri Hita Karana Terhadap Kinerja (Studi pada LPD Se-Kota Denpasar).Skripsi Akuntansi Universitas Pendidikan Nasional..

Dewi, K. K., \& Dwijaputri, A. 2014. Pengaruh Penerapan Prinsip-Prinsip Gcg Pada Kinerja Keuangan Lembaga Perkreditan Desa Kabupaten Fakultas Ekonomi dan Bisnis Universitas Udayana (Unud ), Bali , Indonesia sumber daya yang dimiliki. Tata kelola perusahaan yang baik atau Good Corporate. 3, 559-573.

Made, N., \& Erawati, A. 2017. Pengaruh Penerapan Good Corporate Governance dan Budaya Tri Hita Karana pada Kinerja Keuangan. 19, 421-451. E-Jurnal Akuntansi Universitas Udayana

Mulyawan, I P., Wirama, D. G., Badera, I. D. N. 2017. Budaya Tri Hita Karana Sebagai Pemoderasi Pengaruh Prinsip Good Corporate Governance pada Kinerja Lembaga Perkreditan Desa di Kota Denpasar. E-Jurnal Ekonomi Dan Bisnis Universitas Udayana, 8, 3193-3222.

Nilayani, K. 2016. Budaya Tri Hita Karana sebagai Pemoderasi Good Corporate Governance dan Proteksi Awig-Awig terhadap Kinerja Lembaga Perkreditan Desa (LPD) Se-Kecamatan Gianyar. Skripsi Akuntansi Universitas Pendidikan Nasional..

Nurcahyani, Suhadak, \& Hidayat, R. 2011. Pengaruh Penerapan Good Corporate Governance dan Kepemilikan Institusional terhadap Kinerja Keuangan (Studi pada Perusahaan Peserta Cgpi yang Terdaftar di BEI Tahun 2009 - 2011). Jurnal Administrasi Bisnis S1 Universitas Brawijaya 
Omika, I. G. A., \& Biyantari, N. K. 2017. Pengaruh Budaya Tri Hita Karana Pada Hubungan Corporate Social Responsibility Dan Nilai Perusahaan Pada Indonesia Tourism Development Corporation. 2(2), 247-258.

Omika, I. G. A., Pradnya Dewi, I. G. A., Kustina, T., \& Das Prena, G. 2018/ Culture of Tri Hita Karana on Ease of Use Perception and Use of Accounting Information System. 2(2), 77-86.

Parmawan, I. G. P., Sujana, E., \& Purnamawati, I. G. A. (2017). Pengaruh Internal Control, Budaya Etis Organisasi, Kesesuaian Kompensasi, Dan Proteksi Awig-Awig Terhadap Kecenderungan Kecurangan ( Fraud) (Studi Pada Lembaga Perkreditan Desa di Kecamatan Kubutambahan ). eJurnal S1 Ak Universitas Pendidikan Ganesha (Vol: 8 ) No:2 Tahun 2017

Pradnyani. 2018. Pengaruh Good Corporate Governance dan Manajemen Risiko pada Kinerja Keuangan Koperasi di Kabupaten Badung. Skripsi Akuntansi Universitas Pendidikan Nasional..

Prasinta, D. 2013. Pengaruh Good Corporate Governance Terhadap Kinerja Keuangan. Accounting Analysis Journal, 2(2), 1-14.

Putri, D., Ulupui, \& Wirawati, P. 2017. Pengaruh Good Corporate Governance dan Budaya Tri Hita Karana pada Kinerja Bank Perkreditan Rakyat. Jurnal Ilmiah Akuntansi dan Bisnis, Vol 12, No.1, Januari 2017

Setyawan, K., \& Dwija Putri, I. 2013. Pengaruh Good Corporate Governance Terhadap Kinerja Keuangan Lembaga Pekreditan Desa Di Kecamatan Mengwi Kabupaten Badung. E-Jurnal Akuntansi, 5(3), 586-598.

Sugiyono. 2017. Metode Penelitian Bisnis Pendekatan Kuantitatif, Kualitatif, Kombinasi, dan R\&D (3rd ed.). Bandung: Alfabeta.

Sujana, E., Saputra, K., \& Mandirta, T. 2018. Perspektif Budaya Lokal Tri Hita Karana dalam Pencegahan Kecurangan pada Pengelolaan Dana Desa. 1(1), 28-41. Artikel Reviu Literatur 